\title{
DAVID HELPS
}

University of Toronto

\section{"New York is Dying”: Policing Outdoor Sex Workers in the Era of AIDS and Urban Renewal, 1981-88}

Sex worker Carol Leigh was twenty-nine years old when New York City experienced its first known AIDS death in early 1981. Leigh first became involved in the sex industry of Manhattan's Lower East Side as a young woman. By the 1980s she was working as a call girl in San Francisco, home of Call Off Your Old Tired Ethics (COYOTE), the sex worker rights organization with the largest national profile at the time. As Leigh remembered in the early 2000s, "I was seeing only five or six regular clients at the time, and most of them were not using condoms." The outbreak of AIDS, as it would come to be known by 1982, prompted COYOTE to increase their safer sex education work, an effort Leigh only halfrealized would be essential to countering new legislative and rhetorical attacks on sex workers' livelihoods. "Little did I imagine," Leigh would later recall, "that my adventurous bent would cast me into a modern day leper's role." ${ }^{1}$

As a number of scholars have demonstrated, sex workers have historically become scapegoats in times of heightened moral anxiety. ${ }^{2}$ However, work remains to be done to foreground the policing of sex work within the overlapping stories of AIDS and "urban decline." These stories have been studied at length and each is closely associated with New York City in the American imagination. But their corresponding moral panics entangled New York sex workers in ways that can further our understanding of the histories of sexuality, policing, urban space, law, and American culture more broadly. This essay will explore how official and popular discourses surrounding HIV/AIDS and "urban decline" converged to target sex

\footnotetext{
${ }^{1}$ Carol. Leigh, Unrepentant Whore: The Collected Work of Scarlot Harlot (San Francisco, CA: Last Gasp, 2004), 80-1.

${ }^{2}$ For the European context, see Roger. Davidson and Lesley A. Hall, eds., Sex, Sin and Suffering: Venereal Disease and European Society since 1870 (New York: Routledge, 2001). See also Becki L. Ross, "Sex and (Evacuation From) the City: The Moral and Legal Regulation of Sex Workers in Vancouver's West End, 1975-1985," Sexualities 13, no. 2 (2010): 197-217; Philippa. Levine, Prostitution, Race, and Politics: Policing Venereal Disease in the British Empire (New York: Routledge, 2003).
} 
workers, particularly street-based women, often referred to as "streetwalkers." ${ }^{3}$ It focuses on the Lower East Side (including Alphabet City) and the area surrounding Times Square- two sites central to the battles over urban space and New York City's sex industry. Narrowing our aperture allows us to reconstruct the everyday contests which took place over particular sex-working bodies and spaces and not others.

Three sources of power interacted to put streetwalkers at the centre of fears about the city's moral and physical health. First, New Yorkers seized on an image of their city since the mid-1970s as a dangerous and vice-ridden metropolis to denigrate sex workers. Newspaper coverage and editorials, as well as blockbuster films set in New York City contributed to these anxieties. Metaphors of diseaseincluding the language used to describe AIDS - were readily deployed against sex work to "explain” New York's state of moral and social sickness. Second, medical studies, which were decontextualized and disseminated in newspapers, posited sex workers as a pathogenic pathway between the gay and straight populations. As the media narrative shifted from one of an inexplicable disease limited to the gay community to something all Americans should worry about, the figure of the streetwalker became both an appealing explanatory device and a solemn moral warning, demarcating the boundaries of acceptable behaviour. Third, as part of a larger campaign to "clean up" blighted areas, the New York Police Department became increasingly aggressive towards outdoor sex workers. Despite the neutral language of New York State's prostitution law after 1978, arrests continued to disproportionately affect women working from the street. These factors combined to make street-based women in the sex trade a moral and biological threat to a New York City imagined as sick and weakened by AIDS and the urban crisis.

These discourses were created by historical actors-people with the officially-sanctioned occupational power to "know" and make known-including police, scientists, journalists, developers and members of government. An analysis of

\footnotetext{
${ }^{3}$ In this essay, "street-based" refers to women who solicited clients outdoors as opposed to sex workers based in brothels and massage parlours, or "call girls" operating through a dispatcher. I will attempt to use the least stigmatizing language possible, such as "outdoor sex worker" or "street-level sex worker." Where I employ the term "streetwalker" it is as a socially-constructed category or imagined character in the popular imagination of the city.
} 
these discourses allows us to account for how power was mapped onto sex workers' bodies, but a one-directional bird's eye view of history obscures as much as it reveals. As contested sites, the streets of New York City provide a crucial vantage for studying policing. I take seriously Michel de Certeau's call to "bring to light the clandestine forms taken by the dispersed, tactical, and makeshift creativity" of marginalized actors "caught in the nets of discipline." ${ }^{4}$ Writing this history, then, means emphasizing moments of friction between people with unequal access to power. Discourse was never monolithic or uncontested: sex workers met an array of popular assumptions about them by organizing and attempting to forge a counternarrative. Their pursuit of self-representation was not always successful, but they used whatever resources were available to them, in order to mount moments of resistance and share strategies of survival within their ranks.

\section{The Urban Crisis and the Perpetual Death of New York City}

The vilification of street-level sex workers built on a social imaginary of New York City that was highly familiar to residents and non-residents alike. New Yorkers themselves drew upon an iconography of characters who embodied the city's vicious excess and squalor, its corruption and deprivation, its thrills and terror. Films heightened the association between New York and the sex industry by depicting the city as an "ever-present world of drugs and prostitution." ${ }_{5}^{5}$ Perhaps no example is more representative of this image of New York City than Taxi Driver (1976), directed by Martin Scorsese on his way to becoming arguably the city's most celebrated filmmaker. Driven mad by the urban sleaze which he cannot escape, protagonist Travis Bickle expressed a homicidal desire to wipe the "scum" off the city's streets. The film contained all the hallmark characters of seedy New York: a violent and murderous working-class stiff, a prostitute with a history of being abused, members of the mafia, and a corrupt political class. Films like Taxi Driver amplified the dire economic situation of the city with a cinematography of municipal squalor and moral decay. In 1975, the New Tork Daily Nerws famously plastered

\footnotetext{
${ }^{4}$ Michel de Certeau, "General Introduction," in The Practice of Everyday Life (Berkeley, Calif: University of California Press, 1984), xiv-xv.

${ }^{5}$ Stanley Corkin, “Sex and the City in Decline: Midnight Cowboy (1969) and Klute (1971)," Journal of Urban History 36, no. 5 (2010): 628.
} 
“FORD TO CITY: DROP DEAD” on its cover when the president scoffed at proposed bailout. ${ }^{6}$ In the years that followed, many New Yorkers believed their city was well on its way to that fate.

The cinematic image of a dying New York City, simultaneously depraved and underdeveloped, continued to resonate in the 1980s. Manhattan's Brian De Palma released Dressed to Kill in 1980-in which a New York prostitute is implicated in a murder - to critical acclaim and strong box office receipts. In Escape From New York (1981), set seven years into the future, Manhattan has been converted into a colossal super-prison following a 400\% increase in crime. Fear City (1984), directed by lifelong New Yorker Abel Ferrara, mapped a lurid geography of Times Square with a plot centred on a serial killer who preys on strippers. Other examples included the mobster film Alphabet City (1984) and zeitgeist-defining $W$ all Street (1987), both written and directed by New Yorkers.

This trend culminated in the decade-capping eighth installment of the Friday the $13^{\text {th }}$ franchise, subtitled, Jason Takes Manhattan (1989). The film's poster [Figure 1] shows the iconic hockey mask of Jason, the series' villain, bathed in the neon red glow of a red light district like Times Square. Jason's mask is almost superfluous in his new home: the city's density ensures his anonymity in ways the summer camp setting of the original film could not. Below Jason's mask is a Manhattan skyline, which fades into his bloody red portrait while being pierced by a knife Jason is wielding. Hovering above the entire scene is the film's ominous tagline: "NEW YORK HAS A NEW PROBLEM,” a not-so-subtle allusion to the social contradictions of a city divided by race and class, one where metropolitan glitz can never contain spectacles of violence.

${ }^{6}$ Corkin, “City in Decline," 631. 
In this cultural landscape, it should come as no surprise that New Yorkers drew on the tropes of these popular films to express their disdain for outdoor sex workers. The "streetwalker," "hustler" or "hooker" was one of the central symbols in the tense response to New York's economic crisis, joined by the "bag lady," the "drug pusher," and the "vagrant."

Tabloids and "serious" newspapers alike announced "NEW YORK IS FACING 'CRISIS' ON VAGRANTS"7 or warned "City's Prostitutes Invade Residential Communities.” One columnist described Times Square's denizens as "hustlers, thieves, prostitutes,

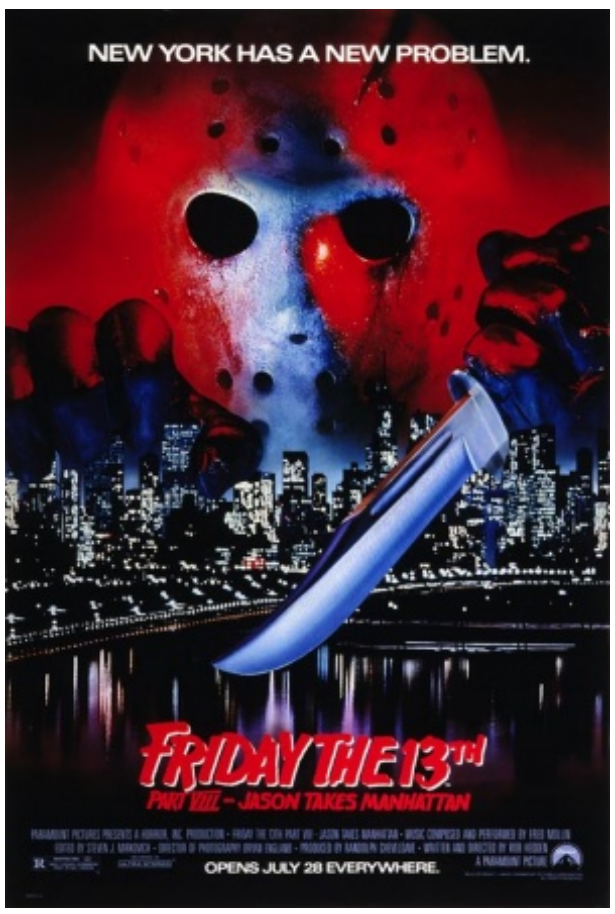

Figure 1 cripples, derelicts, winos, molesters, monsters, droolers, accosters." ${ }^{9}$ Since the populations that experienced homelessness, drug addiction, and sex work overlapped, the discursive figures of urban decline could be made interchangeable. The homeless population could be styled as "a Sordid Sea" bringing "tides of prostitution, drug and gun sales and thievery." 10 What these imagined undesirables had in common was that they revealed serious cracks in the liberal capitalist vision of the postwar city, of which New York was but one example.

It was not just New Yorkers with journalism posts or Hollywood studios behind them who tapped into a rich iconography of a dying city. By writing letters to newspapers, citizens gained momentary access to mass discourse and contributed to the stigmatization of sex workers and other residents on the margins. In 1986, a Midtown homeowner expressed how her sympathy for street-based populations

\footnotetext{
${ }^{7}$ Deirdre Carmody, "NEW YORK IS FACING 'CRISIS’ ON VAGRANTS: Residents Fighting Efforts to Put Shelters in Their Communities Vagrants in New York Are Facing 'Crisis' in Neighborhood Hostility 36,000 Homeless in City A Danger in Large Facilities,” Nerw York Times, June 28, 1981.

${ }^{8}$ Barbara Basler, “City's Prostitutes Invade Residential Communities," New York Times, Late Edition (East Coast), August 15, 1981, sec. 1.

${ }_{9}^{9}$ Phillip Lopate, quoted in Jonathan M Soffer, Ed Koch and the Rebuilding of New York City (New York: Columbia University Press, 2010), 271.

${ }^{10}$ The Economy of the Homeless; Children in a Sordid Sea," New York Times, Late Edition (East Coast), December 5, 1985, sec. A.
} 
became tempered by her daily interactions with homeless people. The author lamented that "New York City has dumped 45 percent of its homeless people" in her neighbourhood, a sure sign that local government had "gone insane." At the centre of her complaint was "the flagrant sale" of sex and drugs, and she minced no words about what this meant for respectable citizens: "We the taxpayers of the neighborhood have become the prisoners of the welfare people," she accused. Having internalized the political mood of the Reagan era (characterized by public divestment and the War on Drugs), this homeowner conflated urban squalor and prostitution - each supposedly enabled by city mismanagement-into the figure of an obstinate underclass, "the welfare people." 11

\section{Times Square and the Lower East Side: Old Battlegrounds, New Ideas}

No area was more closely associated with commercial sex and urban decline in the city's social imagination than Times Square, what the New York Times called the centre of "sin and decay." In Tales of Times Square, published in 1983, journalist Josh Alan Friedman, described the area as "miserable, ghastly," and a "witches' brew" where the "official dregs of society" mix with the "scum of the earth." With lines like, “[a] Puerto Rican pre-op transsexual stabs a trick in the eye with a sharp fingernail to grab his cabfare" and "300-pound hookers flip out their hooters to stop traffic," Friedman made special effort to emphasize the violence and depravity of sex workers in racialized, transphobic, and fat-phobic terms. This reputation gave the section of Eighth Avenue between $41^{\text {st }}$ and $42^{\text {nd }}$ Streets, the area around Times Square, the NYPD nickname of “Asshole Alley.” Lest any reader of Friedman's muckraking wonder who was the most distasteful of these characters, Friedman placed "streetwalkers" at the base of this urban food-chain- "bottom feeders in the hierarchy of hookers." Friedman's language was among the most extreme used to denigrate Times Square's sex workers, but he was not an outlier. Even state officials drew on similarly medical and zoological metaphors, including a judge who decried the "flotsam and jetsam prostitutes," those "purveyors of poison." Like a body with an untreatable infection, these undesirables "resisted one cleanup after another."

11 "PEOPLE WHO LIVE SOMEWHERE MEET PEOPLE WHO LIVE NOWHERE: [Letter]," New York Times, Late Edition (East Coast), September 29, 1986, sec. A. 
"Times Square," he declared, represented nothing less than "the nadir of our society." 12

If any neighbourhood challenged Times Square for its claim to being the sex trade capital of New York City, it was the Lower East Side and the adjacent Alphabet City. Efforts to clean up this section of Manhattan began later than Times Square, but were no less significant. The Lower East Side had been one of the centres of New York's commercial sex network since the late nineteenth century. By the late 1970s, as landlords walked away from their buildings and municipal disinvestment became more severe, the most derelict parts of the area became a "no man's land” where only Puerto Rican families, students, artists, and activists remained. In 1985, the NYPD took developers' calls to clean up the area seriously, and launched "Operation Pressure Point" to wipe-out sex work, drug dealing, and petty theft in Stuyvesant Square in Alphabet City. ${ }^{13}$

These locales had long histories of housing New York's licit and illicit sex industries. Likewise, homelessness in New York City had undeniably become a crisis by the early 1980s. The number of households mired below the poverty line jumped 25 percent between 1978 and 1985. The city counted 36,000 homeless people in 1981 and faced a court order to build significantly more social housing units. Council appealed to every one of its community boards to accept a shelter for 200300 people. When each refused, the city resorted to building a new shelter on the nonresidential Wards Island in the East River. By that winter, the supply of shelters was so inadequate that the city began housing homeless people in state armouries, including one where 160 men shared just three sinks, three toilets, and four urinals. The following year the number of homeless people was the highest the city had seen since the Great Depression. In January of 1983, one letter to the New York Times

12 “A TIMES SQUARE REVIVAL?," New York Times, December 27, 1981, Late Edition, sec. Magazine Desk, 6; Josh Alan. Friedman, Tales of Times Square (New York: Delacorte Press, 1986), 51, 133, 161; Judge Jay Stuart Dankberg, quoted in Themis Chronopoulos, Spatial Regulation in New York City: From Urban Renewal to Zero Tolerance (New York: Routledge, 2011), 69.

${ }_{13}$ Christopher. Mele, Selling the Lower East Side: Culture, Real Estate, and Resistance in New York City (Minneapolis: University of Minnesota Press, 2000), 45; Christopher Mele, "Gentrification in Alphabet City," in From Urban Village to East Village: The Battle for New York's Lower East Side, ed. Janet L. Abu-Lughod (Cambridge, USA: Blackwell, 1994), 171; Keith Schneider, “As Night Falls, Crime Moves Into Stuyvesant Square: Crime Moves In to Stuyvesant Square,” New York Times, October 12, 1985, sec. Metropolitan Report. 
offered a cynical assessment: with homelessness increasing despite the 10,000 empty residential buildings, "New York’s 'Best Housing Hope' is Dying." ${ }^{4}$

This rise in homelessness in fact came as New York City's economic fortunes were improving. By 1983 it was a hub for the finance and information technology industries, and the city seemed to be turning the corner. But these new jobs were outpaced by the exodus of semiskilled work which forced the city's more precarious workers into the growing service economy, if they found work at all. The influx of highly skilled workers with new tastes combined with an economic emphasis on tourism, provoking rampant real estate speculation that sped a nascent gentrification. In this way, New York's renewal was a matter of perspective: the top 20 percent of earners pocketed half of all income increases, as city hall diverted resources from social welfare programs to what Themis Chronopoulos terms "spatial regulation." With none of the rights available in the formal labour market, and as the most exposed of their kind, outdoor sex workers' place within the changing city was especially at risk. ${ }^{15}$

Spurred by community (and developers') pressure to clean up blighted areas, Mayor Ed Koch doubled-down on urban planning efforts that accelerated gentrification and exacerbated homelessness. Times Square was the primary target of the city's urban renewal grand strategy. As Chronopolous writes, “Times Square made New York seem like a city in decline, a city that had been overtaken by lowincome people who acted in a disorderly fashion." ${ }^{16}$ Mayor Koch's vision meant “making New York a middle-class public space," and the Times Square renewal project was no exception. ${ }^{17}$ After lampooning a plan to build a two-story combination shopping mall-theme park complete with state of the art IMAX theatre, the mayor settled on a less Disney-inspired project. ${ }^{18}$ The construction of two office towers would replace Times Square's reputation for raucous free-market

\footnotetext{
${ }^{14}$ Claire H Cooney and Janet Quint, "Prostitution in New York City: Answers to Some Questions" (New York Women in Criminal Justice, June 1977), National Criminal Justice Reference Service, 2-A; Mele, Selling, 45, 228-31; Soffer, Ed Koch, 256-7, 280; Carmody, “CRISIS’ ON VAGRANTS,” sec. 1; “The Homeless Won't Go Away,” New Tork Times, August 23, 1982; Mele, “Gentrification,” 172-86; "LETTERS: New York’s 'Best Housing Hop’ Is Dying",” New York Times, January 22, 1983, sec. Editorial Desk.

${ }^{15}$ Soffer, Ed Koch, 256-7, 280; Chronopoulos, Spatial Regulation, 83, 90.

${ }^{16}$ Chronopoulos, Spatial Regulation, 71-2.

${ }_{17}$ Soffer, Ed Koch, 285.

${ }_{18}$ Soffer, Ed Koch, 272.
} 
fun with a sense of sleek "corporate sterility." 19 The 42nd Street Development Corporation spearheaded the project and took up journalists' and citizens' language of stagnation. Accused in December 1981 of disguising moral cleansing as urban uplift, the Corporation's president responded, "This isn't a crusade to clean up drugs or prostitution. It's a development plan." Yet in the same breath he revealed the rhetoric of moral hygiene which undergirded this mere "development plan": "as long as the street is a garbage can, nothing can be done here." 20 In a later public statement, the Corporation cited the square's "human decay," evidenced by its “vagrants, pimps, pushers, [and] prostitutes," a decay that was "spreading" like a "cancer" and "threaten[ed] the life of everything around it."21 In March 1982, as these developers readied themselves to demolish two historic theatres, one reporter announced that "the battle for Times Square is now begun." 22

\section{“STAY OFF OUR STREETS”: Community Mobilization and Police Crackdown}

In 1978 the State of New York had amended its laws on prostitution, removing the distinction between purchasing and selling sex. Johns were now as culpable as sex workers. In practice, women practicing sex work continued to be arrested far more frequently than their clients, despite the fact that there were more men paying for sex than women selling it. ${ }^{23}$ When Mayor Ed Koch took to the radio airwaves for "The John Hour” it took him just one minute to list a week's worth of johns arrested in the city. ${ }^{24}$ An NYPD officer himself confirmed that, "We rarely bust the johns. Believe it or not, we're told not to because it's more important for us to be on patrol where we can keep some order on the streets rather than being at the precinct processing a john.” ${ }^{25}$ It was not just that johns got off easy-policing prostitution had long meant targeting certain bodies and spaces more than others.

\footnotetext{
${ }^{19}$ Soffer, Ed Koch, 274.

${ }^{20}$ Quoted in “A Times Square Revival?” Magazine Desk, 6.

${ }^{21}$ Quoted in Friedman, Tales, 148.

22 Russell Baker, “OBSERVER; Easterin’ To Glory: [op-Ed],” New Tork Times, Late Edition (East Coast), March 27, 1982, sec. 1.

${ }^{23}$ Frances P. Bernat, "New York State’s Prostitution Statute," Women E̊ Politics 4, no. 3 (October 1, 1984): 103-20; Cooley and Quint, “Prostitution,” 12-B.

24. Soffer, Ed Koch, 323.

${ }^{25}$ Quoted in Michael. Zausner, The Streets: A Factual Portrait of Six Prostitutes as Told in Their Own

Words (New York: St. Martin's Press, 1986), 145.
} 
As two activists wrote in 1977, "Although 'the statutes bar male or female prostitution in apartments, brothels, massage parlors, and hotels, enforcement efforts are, in fact, directed almost exclusively against streetwalkers, who tend to be poorer women of minority groups." They found that, "Street solicitation is at the center of what is considered the 'prostitution problem' and is regarded as a threat by both residential and commercial interests.” ${ }^{26}$ By 1983, the NYPD’s Public Morals Division had confirmed that it rarely intervened in indoor sex work. ${ }^{27}$

Little changed with the 1978 reform law: because police directed more resources to areas marked-out for urban renewal, areas where sex workers were more likely to be street-based and from marginalized groups, policing continued to punish the most stigmatized women in the industry. One 1980 sociological study found that black and Latino women made up about half of all visible sex workers, but constituted more than two-thirds of the arrests. That this was a period when roughly nine out of every ten NYPD officers were white-and women officers were almost unheard of-suggests that individuals' racism and sexism played a role. But personal prejudices are only part of the story: police presence and urban renewal campaigns were both responses to direct calls from respectable citizens: the degree of police presence correlated with the "degree of community consciousness" about prostitution. This "community consciousness" sometimes meant targeting sex workers in the wake of unrelated events, such as when Lower East Side residents erected banners warning "PIMPS-WHORES-JOHNS STAY OFF OUR STREETS" after a young girl was murdered in a nearby park. ${ }^{28}$

Mayor Koch and the NYPD got the message. By August 1983, police sweeps of Times Square targeting theft, drug sales and prostitution tripled arrests for the area. In all, 17,000 sex workers were arrested in New York City that year, almost all of them while working the streets. The 1985 city budget promised to spend $\$ 50$ million over two years to hire 1,000 more officers, giving New York its largest police force since 1976. At the press conference, Police Commissioner Benjamin

\footnotetext{
${ }^{26}$ Cooley and Quint, "Prostitution," 10-B, 12-B.

${ }_{27}$ Elaine Sciolino, “Off the Street, Prostitution Is Flourishing," New York Times, Late Edition (East Coast), November 14, 1984, sec. B.

${ }^{28}$ Bernard Cohen, Deviant Street Networks: Prostitution in New York City (Lexington, Mass.: Lexington Books, 1980), 43, 80-1, 76, 117-118.
} 
Ward, like Ed Koch, made a populist connection to the NYPD's anti-street crime crusade: "We're going to go out there and take the streets back from the hoodlums and give them back to the people." The sharp distinction made between street-based hoodlums and "the people" suggested the city's criminal underclass did not count as "people" at all. Ward and Koch continued to make "quality of life" policing a top priority, by diverting 1,485 police from over a hundred precincts away from the 911 dispatch and tasking them only with preventing "low-level" crimes like prostitution. The NYPD's strategy reflected a police view that preventing the sale of sex would benefit the whole of society. As one New York-published police manual had already argued, only "assertive and discerning patrolling” prevented the murder of a vulnerable "street girl": a misfortune which consumes "the major concentration of police resources." 29

Aggressive policing was the first of the city's two-pronged approach. The other was municipal spending to court investors and tourists. By the end of 1983, Koch had promised $\$ 1.6$ billion for redevelopment to rid Times Square of its reputation as an area "plagued" by "prostitution, drug peddling and decay," as the Washington Post put it. This was language Koch himself would have approved of: five months later he gave Times Square a clean bill of health, contrasting the presentday area-which reported a decrease in sex-related businesses—with the New York of the late 1970s, "infested with pimps, prostitutes and johns." Parks were another contested site: for example, City Hall pumped millions of dollars in renovations into Union Square Park and established curfews for others. ${ }^{30}$

Residents still believed that New York's Finest were not doing enough to make their communities safe and sex work-free. The Lower East Side banner-

\footnotetext{
${ }^{29}$ Philip Shenon, “Times Sq. Area Sweeps Have Tripled Arrests: Arrests Tripled by Police Sweeps Of Times Sq. Area on Weekends," New York Times, August 22, 1983; Sciolino, “Off the Street," sec. B; Michael Goodwin, "Koch Budget For '85 Allots Funds To Hire 1,000 More Officers,” New York Times, April 19, 1984, Final Edition, sec. Metropolitan Desk, A; Jesus Rangel, "MORE POLICE TO COMBAT ‘QUALITY OF LIFE’ CRIMES,” New Tork Times, January 24, 1985, Final Edition, sec. Metropolitan Desk, B.; Jesus Rangel, "New York City Police Commissioner Benjamin Ward Says Police Department Is...," New Tork Times, January 24, 1985, sec. 2; David Powis, The Signs of Crime: A Field Manual for Police (London; New York: McGraw-Hill, 1977), 112.

${ }^{30}$ Merrill Brown, "N.Y.'s Times Square to Get Face-Lift: Developer, City Officials Announce \$1.6 Billion Office Complex: \$1.6 Billion Project Set for New York’s Times Square Area," Washington Post, December 21, 1983, sec. Business \& Finance; "Sex Business in Times Square Said to Decrease," New Tork Times, Late Edition (East Coast), May 31, 1984, sec. B; Schneider, “As Night Falls,” sec. Metropolitan Report.
} 
makers were just one of a number of community groups that formed in response to prostitution. ${ }^{31}$ The owner of a penny arcade in Times Square looked to New York's anti-vice history for an old-timey solution, quoting former police commissioner Theodore Roosevelt: “'Men, don't make any arrests. There's more law at the end of a nightstick than all your courts put together." 32 In 1982 Police Magazine warned East Coast cops that "A small army of street prostitutes" from the Midwest was on the march to New York City. ${ }^{33}$ Josh Alan Friedman, the journalist who lamented street-walking "bottom feeders," offered his own characteristically sensationalistic solution: "Sure, the cops could launch a paramilitary campaign against this inhuman contamination, and fill up Madison Square Garden with arrests," he mused. "It poses an interesting argument for one little night of fascism.” 34

Of course, Friedman's comments about the desirability of a police-led Kristallnacht were far from typical. In reality, most New Yorkers would have balked at such a proposal. Nonetheless, the actions police took in response to public pressure demonstrates at best disrespect, and at worst disdain, for street-based women. As an eighteen-year-old black sex worker called Juicy recounted, "Most of them [police] are okay, but some of them are real assholes. They get off on harassing us." ${ }^{55}$ Latrice, aged nineteen, and also black, told an interviewer, "The police are supposed to protect us but they never seem to be around when you need them.” Latrice alleged that sadistic officers took to smacking sex workers' legs with their billy clubs without provocation, which another interviewee confirmed. ${ }^{36}$ One woman recalled being blackmailed into performing oral sex on an officer. ${ }^{37}$ Sex worker and activist Carol Leigh spoke for a whole community when she demanded, "How can we protect ourselves from the pimps and rapists when we're so busy protecting ourselves from the police?" 38

\footnotetext{
${ }^{31}$ E. R. SHIPP, "Residents of Many New York City Neighborhoods, Exasperated by What They See...," New York Times, July 30, 1983, sec. 1.

${ }^{32}$ Quoted in Friedman, 53.

33 Bernard Edelman, "Shaking Down Atlantic City,” Police Magazine, November 1982, 44-5.

${ }^{34}$ Friedman, Tales, 137-8.

${ }^{35}$ Quoted in Zausner, The Streets, 38.

${ }_{36}$ Quoted in Zausner, The Streets, 56-7, 118.

${ }^{37}$ Quoted in Arlene. Carmen, Working Women: The Subterranean World of Street Prostitution (New York: Harper \& Row, 1985), 137.

${ }^{38}$ Carol Leigh, "The (Bad) Girl Next Door," in Unrepentant Whore: The Collected Work of Scarlot Harlot (San Francisco, CA: Last Gasp, 2004), 47.
} 


\section{The AIDS Crisis and "Streetwalker" Scapegoating}

Cut off from the protections of the law and stigmatized by a moral panic, sex workers made a consequence-free target for vindictive police. With people like columnist Sydney Schanberg labeling entire sections of New York City "diseased areas" slowly dying of the "cancer" of urban decline, anxieties about sex work were not about to subside. ${ }^{39}$ But another moral panic emerged during the 1980 s which pushed sex work to the centre of popular and political debates about the health of New York and its residents. The same language of declension, sickness, and moral deviance proved highly transferrable to talking about AIDS - an urban-centred epidemic first identified in marginalized populations which came to represent the excesses of the 1960s and 70s. As it became clear HIV/AIDS could afflict heterosexual Americans, sex workers represented an appealing link between sexual communities. Medical discourse, disseminated to a wider audience by major newspapers, posited prostitution as a mechanism by which this terrible disease could be passed — or was already being passed — and therefore threatening countless (respectable) lives.

There was a tentative logic to the association of sex work and HIV/AIDS. Casual sex had certainly played a role in transmitting AIDS up to this point. That New York's sex workers might have sex with several clients in one day suggested they might be more likely to contract the virus and spread it to other clientsassuming they were not using barrier prophylactics. Yet there was also a dimension of this proposition which had nothing to do with scientific hypotheses. When a strong epidemiological link between sex workers and the transmission of AIDS failed to materialize, scapegoating did not decline. Beyond the medical possibility, then, was a popular preconception that sex workers were dirty and sick, irresponsible and careless, even malicious. In the midst of the AIDS crisis, Allan Brandt and others expressed a strong sense of historical déjà vu: "AIDS, like other sexually transmitted diseases in the past, has been viewed as a fateful link between

\footnotetext{
${ }^{39}$ Sydney H Schanberg, "NEW YORK: 'I Live Here and You Don't', 'New York Times, October 24, 1981, Late Edition, sec. Editorial Desk, 1.
} 
social deviance and the morally correct." The AIDS crisis unfolded within a long history of sex work and disease scares, demonstrating that public health justifications for the policing of sex work bore little relation to the reality of the illness itself. Just as moral panics about the white-slave trade and venereal disease pathologized sex workers in periods past, New York's AIDS crisis cast sex workers as morally tainted, like an infection to be handled in the most severe and aggressive ways possible. ${ }^{40}$

As "gay pneumonia" appeared in the heterosexual population, New Yorkers became increasingly worried. New York City was the epicentre of the crisis, home to 42 percent of known cases in the US in 1983. By the summer of 1985, a Manhattan gynecologist was overwhelmed with appointments for straight women concerned they might be at risk, calling AIDS "the new scare." From the medically secure vantage of the Western world, epidemics seemed a thing of the past: "Not since the polio epidemics of the 1950 s has fear of infection reached such a high pitch as it has in the 1980s," wrote Allan Brandt. Important news came on November 5, 1985, as the New York Times announced "Prostitutes' Impact On Spread Of AIDS Is Debated," then revised the last word to the more substantial "Developed" in its late edition. Despite scientists agreeing that "the number of AIDS cases spread by prostitutes" was "miniscule," a number of scientists and physicians registered a belief that "prostitutes could transmit the virus to many men, who in turn will infect their unsuspecting wives and lovers." Just as the newspaper had announced the advent of the "battle for Times Square," these medical developments demonstrated that a renewed battle over sex workers' bodies was beginning. ${ }^{41}$

It was during this part of the decade that American AIDS research made sex workers' bodies what Becki L. Ross would call an "object of inquiry.” ${ }^{2}$ The idea that

\footnotetext{
40 Allan M. Brandt, “AIDS and Metaphor: Toward the Social Meaning of Epidemic Disease,” Social Research 55, no. 3 (1988): 428; Beth Bergen, “AIDs, Prostitution, and the Use of Historical Stereotypes to Legislate Sexuality,” John Marshall Law Review 21, no. 4 (1988): 777-830. ${ }^{41}$ Soffer, Ed Koch, 310 ; Sara Rimer, "FEAR OF AIDS GROWS AMONG HETEROSEXUALS," New Tork Times, August 30, 1985, Late Edition, sec. A; Brandt, “AIDS,” 426; Erik Eckholm, "Prostitutes' Impact On Spread of AIDS Is Debated: Officials Question Link Of AIDS and Prostitutes," New York Times, November 5, 1985, sec. Science; Erik Eckholm, "Prosttutes' Impact on Spread of Aids Is Developed," New York Times, Late Edition (East Coast), November 5, 1985, sec. C. "Prostitutes' Impact on Spread of AIDS is Debated"; "Prostitutes' Impact on Spread of AIDS is Developed"

${ }^{42}$ Ross, "Sex and the City," 198.
} 
prostitution would act as a pathogenic pathway between gay and straight populations had intuitive appeal and was based largely on a new study of seropositive American soldiers and the fact that commercial sex was spreading the virus in Africa. The study found that nine out of 41 patients reported having fifty or more sexual partners, sexual contact with a prostitute, or both. ${ }^{43}$ Whether it was irresponsible of newspapers to suggest this complicated evidence had "developed" the link between sex workers and heterosexual AIDS cases, what is certainly true is that these military personnel had every reason to misrepresent their behaviours. Admitting to homosexuality or intravenous drug use was sufficient grounds for dishonourable discharge (and therefore the loss of important benefits, including pension). Responding to the charge that soldiers had reason to scapegoat prostitution, one of the authors of the 1985 study dismissed such skepticism as mere “wishful thinking." ${ }^{44}$ Sex worker Dolores French was unconvinced, writing in 1988: "in the good-old-boy network of doctors, the military, and male journalists, hookers get blamed for heterosexually transmitted AIDS.”45

\section{The Punitive Turn and Public Health Atrophy}

Despite the tentativeness of the scientific research, medical and journalistic discourse fuelled a legislative firestorm across the United States. New York City's government considered what steps to take, at the same time that a doctor at the NYU Medical Center urged the city to monitor prostitutes. The Surgeon General called for comprehensive education programs "to teach our young people the facts," which pledged Americans to "take precautions" beginning with avoiding sex with someone "who indulges in high-risk behavior" such as a prostitute. ${ }^{46}$ By 1988 , compulsory testing laws for sex workers had been tabled or passed in state legislatures around the country, including in Alabama, California, Florida, Illinois,

\footnotetext{
${ }^{43}$ R.R. Redfield et al., "Heterosexually Acquired HTLV-III/LAV Disease (AIDS-Related Complex and AIDS). Epidemiologic Evidence for Female-to-Male Transmission.," JAMA 254, no. 15 (1985): 2094-96.

${ }^{44}$ Redfield et al., "Heterosexually Acquired HTLV-III/LAV Disease”; Eckholm, "Prostitutes' Impact on Spread of AIDS is Developed."

${ }^{45}$ Dolores French, Working: My Life as a Prostitute (New York: E.P. Dutton, 1988), 233.

${ }^{46}$ Eckholm, "Prostitutes' Impact on Spread of AIDS is Developed."
} 
Nevada, and Washington. ${ }^{47}$ These proposed interventions were not equally invasive, but they shared a concern with regulating the movement and livelihoods of sex workers.

Carceral approaches to sex work and public health made sense considering the moralistic and militaristic language surrounding disease. Police already believed they were waging a war to clean up the streets, a guerilla campaign which the outbreak of AIDS only intensified. As Susan Sontag notes, disease is often discussed in military and policing metaphors: it is "an invasion of alien organisms," for which the body must mobilize "immunological 'defenses," in a unified front with "aggressive" treatments. At a societal level, addressing epidemics amounts to "a fight, a struggle, a war." That understandings of AIDS were loaded with assumptions about deviant behaviour and "high-risk lifestyles," and that it became a pandemic, unconstrained by national boundaries, reinforced this language. As Sontag puts it, the identification of AIDS in the general population made the disease a national moral test: "The survival of the nation, of civilized society, of the world itself is said to be at stake—claims that are a familiar part of building a case for repression." 48

It is also significant that the AIDS crisis took place during the urban crisis in American cities, as deindustrialization took its toll. The image of a dying New York City_characterized by urban blight and squalor-intersected with the coverage of HIV/AIDS. Sex workers were already a casualty of urban renewal campaigns: one article referred to prostitution as the "dirt" of Times Square that needed to be "filter[ed] out." ${ }^{9}$ The goal of the project, according to one developer, was to "retain the best aspects" but "get rid of the garbage." 50 As Mary Douglas has famously shown, "dirt is essentially disorder," and notions of purity are used to order and

\footnotetext{
47 “AIDS Instruction and Local Control," Wall Street Journal, May 19, 1987; Bergen, "Historical Stereotypes," 805-6; Tamar Lewin, "Rights of Citizens and Society Raise Legal Muddle on AIDS: Rights Issues Are Raising Legal Muddle on AIDS At What Point Should Society Isolate Disease Victims?," New York Times, October 14, 1987; Jeanne DeQuine, "AIDS Prostitute Freed Today," USA Today, May 23, 1988, First Edition, sec. NEWS.

${ }^{48}$ Susan Sontag, Illness as Metaphor and AIDS and Its Metaphors (New York: Picador/Farrar, 1990), 97, 98, 173.

${ }^{49}$ Richard J. Meislin, "Filtering the Dirt From the Energy Of Times Square: No One Is Sure Where the Less Attractive Elements of the Area Will Go Next.," New York Times, August 31, 1987, sec. Metropolitan News

${ }^{50}$ Ibid.
}

Past Imperfect Vol. XX 
cleanse society. ${ }^{51}$ In the eyes of urban renewal campaigners, New York was a declining city overrun with sick people, whether sex workers, people with HIV/AIDs, or both.

This punitive turn compounded the lacklustre public health response in New York City. The types of solutions people with HIV/AIDS had called for early in the decade were never prioritized. In 1982, the city's health commissioner turned down emergency funds from city council, reflecting the Koch administration's commitment to balancing the budget for that fiscal year. Mayor Koch announced three years later that an additional $\$ 6$ million would be put to use against AIDS, but it was a deeply unsatisfying promise, given that it somehow had to be divided between subsidized housing, hospitals, education, hospice care, and research funding. New York did not open its first anonymous testing centre until November 1986, lagging behind other major cities. When it opened, one counselor recounted being quizzed by a bisexual man who had just tested positive on how to blame his newly discovered infection on sleeping with a prostitute rather than reveal his affairs with men. Gentrification also mounted during these years, while Koch's ambitious multi-year social housing plan became bogged down by bureaucracy, corruption allegations, and compromises. Already marginalized, women in the sex industry had to contend with new forms of punishment and an underfunded patchwork of social services. ${ }^{52}$

By the end of the 1980s, the medical community reached something of a consensus that the link between sex workers and HIV/AIDS was grossly exaggerated. In 1987 the Center for Disease Control concluded that sex workinvolved women were about as likely to test positive as women without involvement. Epidemiologists pointed out that other factors were more significant than simply being in the sex trade, a fact evidenced by the extreme variability in studies' findings. Rates across US cities in 1987 varied from o percent in the legal brothels of Las Vegas-where testing positive meant being fired-to 57 percent in one study of New Jersey sex workers recruited mostly through drug treatment

\footnotetext{
${ }^{51}$ Mary Douglas, Purity and Danger: An Analysis of Concepts of Pollution and Taboo (London: Routledge \& Kegan Paul, 1978), 2.

${ }^{52}$ Soffer, Ed Koch, 308, 31 1, 302-3; Jane Gross, “At New AIDS Test Center, Lives Are Changed,”

New Tork Times, November 29, 1986, Final Edition, sec. Metropolitan Desk, 1.
} 
programs. In New York City, a study of sex workers' clients found six out of 300 to have the virus, though it was unclear whether any had become infected from the paid sex encounters. Criticism of the 1985 study that spurred the scapegoating frenzy found vindication: in 1987 New York City's Health Department interviewed 20 military men who reported contracting the virus from sex workers and all but two later admitted to other high-risk activity. ${ }^{53}$

\section{Strategies for Survival: Sex Workers Talk Back}

The combined strength of stigmatizing discourse - produced by developers, police, state and city government, and multi-million-dollar media outlets-was enormous. However, relying only on these privileged discourses leaves an impression of uncontested and despatialized power. Sex workers and their organizations found the means to resist stigmatization by publishing memoirs and organizing conferences in cities in North America and Europe. They put particular emphasis on disseminating evidence that sex workers were not the likely cause of HIV/AIDS spreading to the heterosexual population. At their conferences and in their writings, outdoor sex workers also demonstrated safer sex techniques and shared ways to ensure their clients abided by their policies. Even sex workers who did not join associations of their peers demonstrated a class and gender consciousness formed by their experiences with police and other authorities. Aware that they were often being targeted by the very institutions which other populations rely on for protection, sex workers took it upon themselves to share strategies for survival.

Sex workers were well aware that the AIDS crisis had put them in the crosshairs. Sex worker and sex work activist Carol Leigh (AKA Scarlot Harlot) described the "undercurrent of panic" within New York's sex work cultures and the consequential drop in business - driven by media speculation that sex workers were a likely cause of transmission-experienced in the mid-1980s. Now "every cold seemed to portend a shameful death.” For women like Leigh, the AIDS crisis made

\footnotetext{
${ }^{53}$ Bergen, "Historical Stereotypes," 782; Gail. Pheterson, ed., A Vindication of the Rights of Whores (Seattle, WA: Seal Press, 1989), 137-8; Deborah R. Brock, Making Work, Making Trouble: The Social Regulation of Sexual Labour (Toronto: University of Toronto Press, 2009), 169.
} 
agitating for the rights of sex workers all the more urgent. In a flyer, she warned that, "Scapegoating prostitutes will escalate the devastation of this epidemic, increasing hysteria and funneling funds away from much needed education and social services.” Leigh also produced a music video for public television in 1987 titled, "Safe Sex Slut," with the mantra "I won't become disease infected./ Me, I'll be so well protected.” In an appearance on the Arsenio Hall Show that year, she pulled a condom from her bra and shocked the host with the deadpan declaration, "I use condoms all the time. Would you like one?” Women practicing sex work worried both about AIDS, and that even if they successfully avoided contracting it, they would still be scapegoated for the disease. ${ }^{54}$

Sex workers took it upon themselves to demonstrate that they were using safer sex techniques - even when their male clients were not so willing. In her 1988 memoir, Dolores French described her routine of covertly applying a condom with her mouth, to the ignorance of even regular clients. Juicy, the eighteen-year-old black sex worker based near Times Square, told an interviewer, "I've never gotten any diseases because I use rubbers for everything." Queen Bee, another sex worker in Juicy's neighbourhood, boasted, "I've never contracted a disease, because I use rubbers for everything, including hand-jobs.” Juicy herself developed tactics for those clients who "don't want you to use anything": "I try to talk them into it by telling them it's for their own protection. I ask them, 'What if I didn't use a rubber with the guy before you, and he had herpes?' That usually works." When that failed, "I just slip the rubber on with my mouth," she related. "The trick doesn't even know that it's on until we're finished." If Juicy ran out of prophylactics, luckily there was "the rubber man," a sympathetic peddler who sold condoms and cosmetics to the street-based women in the area. ${ }^{55}$

One of the most public ways sex workers countered their own stigmatization was through the organization of sex workers' conferences. Here, newspaper coverage and the official record are inadequate to study the discourse of sex work, as they not only silence the voices of sex workers, but leave the impression that such

\footnotetext{
${ }^{54}$ Carol Leigh, “The Scarlot Vector,” 80-1, 86; Carol Leigh, “The Scarlot Letter,” in Unrepentant Whore, 99; Carol Leigh, "Safe Sex Slut," in Unrepentant Whore, 94.

${ }^{55}$ French, Working, 235; Quoted in Zausner, 118, 40.
} 
silence was total. In conjunction with feminist activists and scholars, the first two World Whores' Congresses in Amsterdam and Brussels in 1985 and 1986 gave women in the sex trade the opportunity to share knowledge and experience across national boundaries. The AIDS virus was a major theme. Using a banana, Dolores French demonstrated how to apply and remove a condom without a john noticing, to the amused delight of the audience, and fellow American Gloria Lockett showed how to apply one with her mouth. "I'd rather lose the money one time," French reminded those assembled, "than lose my life or risk getting incarcerated in an AIDS concentration camp because I test positive for AIDS.” Given the severe punishments being contemplated back in the US during the latter half of the decade, French's comments were not mere invective: "I think these are really gruesome thoughts," she admitted, "but they're fears I have and things I'm trying to avoid." 56 These women relayed the paradox that despite assuming that sex workers would spread disease, police sought to punish and prevent sex work by poking holes in women's condoms or confiscating them altogether. "We have to fight hard because they are the police and they have all the power," Gloria Lockett told the crowd. "But we are continuously trying to fight against this because it's terrible," adding, "this is life!" 57

It made sense that the AIDS crisis raised American sex workers' consciousness about their own place in a moralizing society. Without the rights or protections guaranteed for workers in the formal economy, it was in sex workers' interest to care for themselves in the way the state would not. "It is simply part of a woman's business to protect herself from VD," one activist report put it. ${ }^{58}$ Famed sex worker and activist Margo St. James told an audience in 1987, that already, "during the last fifteen years every streetwalker with any concern for herself has used condoms for blow jobs and intercourse." ${ }^{59}$ According to Gloria Lockett, "Most prostitutes, as has always been said, take care of themselves.” Their livelihood and lives were on the line: "Our bodies are our tools and we know how to take care of

\footnotetext{
${ }_{56}$ Dolores French in Vindication, McPherson, ed., 124.

${ }^{57}$ Gloria Lockett in Vindication, McPherson, ed., 117-9.

${ }^{58}$ Cooley and Quint, "Prostitution," 6-B.

${ }_{59}$ Margo St. James in Laurie. Bell, ed., Good Girls/bad Girls: Sex Trade Workers and Feminists Face to

Face (Toronto: Women's Press, 1987), 83-4.
} 
our bodies," she insisted. ${ }^{60}$ In her memoir, Dolores French recounted a client with visible herpes lesions who tried to force unprotected sex upon her. Her response was scathing, and reveals the seriousness with which she took sexually transmitted infections: "Do you realize that you could have put me out of work for the rest of my life?" she demanded. ${ }^{61}$ This consciousness is inevitably missing from newspaper and epidemiological accounts which render sex workers as pitiful victims or passive vehicles of disease transmission. As the proceedings of sex worker conferences indicate, however, sex workers were acutely aware of the punitive and economic consequences surrounding sexually transmitted infections.

\section{Conclusion: Whose New York?}

The linkages between the homeless and street-based sex worker populations were not hard to notice. Few headlines made the connection between urban blight, the sex trade, and AIDS as explicit as "Runaways of 42nd Street: AIDS Begins its Scourge."62 In spite of this headline, the Times Square renewal campaign had in fact started to have its desired effect on the area. In December 1985, with plans for Times Square's redevelopment underway, at least one hotel reduced the number of units set aside for social housing. The Carter Hotel went from 300 low-income units to just 61 in anticipation of the tourism boost promised by Mayor Koch. ${ }^{63}$ With the city's priorities largely elsewhere, the receding social housing infrastructure tightened the vice on already marginalized New Yorkers. The director of another private shelter, which undertook litigation to successfully evict a sex worker who was operating out of her room, declared "there is something sick and bizarre about a social welfare system where you have to spend money on lawyers." 64 At the same time, sex workers identified the confluence of local and national factors which had made their lives more precarious: "the AIDS crisis, the drug war, the sex panic and gentrification," Carol Leigh predicted, would continue to "escalate everyone’s

\footnotetext{
${ }^{60}$ Gloria Lockett in Vindication, McPherson, ed., 117-9.

${ }^{61}$ French, Working, 236.

${ }^{62}$ Suzanne Daley, "Runaways Of 42d Street: AIDS Begins Its Scourge,” New York Times, May 30, 1988, sec. 1.

${ }^{63}$ Barbara Basler, "Hotel Near Times Square Closes Rooms for Homeless to Cater to Tourists," New Tork Times, Late Edition (East Coast), December 29, 1985, sec. A.

${ }^{64}$ Josh Barbanel, "Private Shelters Evicting Disruptive Homeless People: Some Shelters Evicting the Homeless,” New Tork Times, April 15, 1987, sec. Mertopolitan News.
} 
vulnerability, particularly that of poor women, and particularly those who trade in sex." 65

Carol Leigh would take her case for the protection — rather than policing —of sex workers all the way to Congress. In 1988 she spoke before the Senate Judiciary Committee to argue against mandatory HIV testing for prostitutes and in favour of education, job training, disability payment, IV drug recovery programs and needle exchanges. She accused members of her audience who favoured compulsory testing of hypocrisy: "Some of you have confided to me that it's very important to ensure a clean pool of prostitutes because, after all, boys will be boys," she said. Legislation calling for testing and quarantining, Leigh alleged, in contrast to its public health image, was "designed to ensure that there are clean women to use at the expense of those who will be quarantined." With this rare access to official discourse and the space of federal power, Carol Leigh both created a counter-narrative and urged a radically different type of response to sex work in the AIDS era. ${ }^{66}$

If Carol Leigh had reason to be hopeful about the national response, the situation in New York City showed no signs of changing. In the same year, Alphabet City’s Tompkins Square Park — “a park for the detritus of society” 67 became the lightning-rod for the protracted battle over what type of city New York would be. On August $6^{\text {th }}, 1988$ NYPD officers attempted to enforce a curfew that had been established in response to complaints about prostitution and drug dealing. By even the NYPD's own account, what followed was a disaster. Squatters and activists refused to leave: they chanted "Die yuppie scum!" and hurled projectiles at officers. When mounted police charged into the crowd, the demonstrators unleashed “a hail of fireworks, bottles and debris," leading the officer in charge, Captain McNamara, to call in reinforcements. ${ }^{68}$ Police - many decked out in riot gear-met the crowd with their clubs, sometimes indiscriminately. ${ }^{69}$ As many as three hundred officers from all over the city responded over the next few hours, arriving from fifty

\footnotetext{
${ }^{65}$ Leigh, Unrepentant Whore, 33-4.

${ }^{66}$ Leigh, "My Speech Before the Senate Judiciary Committee," in Unrepentant Whore, 96-7.

${ }^{67}$ Denis Hamill, "Public Parks Without the Public," Newsday, City Edition, June 6, 1988, sec. NEWS.

${ }^{68}$ Robert J. Johnston, Jr., "NYPD Report on Tompkins Square Park Incident” (NYPD, August 23, 1988), 5, https://dc.lib.jjay.cuny.edu/index.php/Detail/Object/Show/object_id/804.

${ }^{69}$ Denis Hamill, “Going Bare-Fisted in the Park," Newsday, City Edition, August 8, 1988, sec. NEWS.
} 
different precincts, meaning many of them were without supervision. ${ }^{70}$ Several officers even covered their badges in order to protect themselves from police misconduct complaints - and still 121 of these were filed. ${ }^{71}$ Much of the bedlam was recorded by onlookers, including TV cameras, and the event quickly became a major news story. As the NYPD's report anxiously admitted, “The pictures of officers striking demonstrators with their nightsticks erase the good will [sic] and praise the department earns every day for its good deeds and heroic actions."72

In the Tompkins Square Park clash, Denis Hamill of Nerwsday saw the culmination of unsolved urban crises combining with a balance of power that had definitively tipped in the favour of wealthy and middle-class New Yorkers. Hamill described the NYPD's "mission" as "to rid this decrepit little meadow of apathy in Alphabet City of those people" who appeared unseemly to "the gentry" wanting "the tranquility of places such as Woodstock, Vt., to prevail in the Lower East Side.”73 Whereas the NYPD had initially marked the park out as a hot-spot for the sale of sex and drugs, after the turmoil they insisted those camped out in Tompkins Square included hundreds of skinheads, a claim that journalists failed to substantiate. ${ }^{74}$ Scandalized by the consensus that police had initiated a "riot," Mayor Koch declared all city parks would remain open through the night for the rest of the summer, a flimsy olive branch that did nothing to address gentrification or the community's distrust of police. Rapid gentrification - symbolized by the chaos in Tompkins Square-combined with the city's inability to manage AIDS led at least one New Yorker to draw on a familiar metaphor. "New York is dying again," the Times lamented. The city had been reanimated after its financial death in the mid-1970s, the paper wrote, but now its last rites were being read again. "Then, as now, many people were saying good riddance." 75

\footnotetext{
70 Johnston, Jr., “NYPD Report,” 5.

${ }^{71}$ Soffer, Ed Koch, 345-7.

72 Johnston, Jr., "NYPD Report," 15.

${ }^{73}$ Hamill, "Going Bare-Fisted."

${ }^{74}$ Ibid.

75 "Police and Protesters Have Clashed Before in Tompkins Square; Gentrification’s Price: [Letter]," New Tork Times, Late Edition (East Coast), August 27, 1988, sec. 1; Russell Baker, "OBSERVER: Up-and-Down Town,” New York Times, September 25, 1990, Late Edition.
} 


\section{Bibliography}

“AIDS Instruction and Local Control.” Wall Street Journal, May 19, 1987.

“A Times Square Revival?” New York Times, December 27, 1981, Final Edition, sec. Magazine Desk; 6.

Baker, Russell. “OBSERVER; Easterin’ To Glory: [op-Ed].” New Tork Times, Late Edition (East Coast). March 27, 1982, sec. 1.

- . "OBSERVER: Up-and-Down Town." New York Times, September 25, 1990, Late Edition.

Barbanel, Josh. "Private Shelters Evicting Disruptive Homeless People: Some Shelters Evicting the Homeless.” New Tork Times. April 15, 1987, sec. Metropolitan News.

Basler, Barbara. “City's Prostitutes Invade Residential Communities.” New York Times, Late Edition (East Coast). August 15, 1981, sec. 1.

- "Hotel Near Times Square Closes Rooms for Homeless to Cater to Tourists.” New York Times, Late Edition (East Coast). December 29, 1985, sec. A.

Bell, Laurie., ed. Good Girls/bad Girls: Sex Trade Workers and Feminists Face to Face. Toronto: Women's Press, 1987.

Bergen, Beth. "AIDs, Prostitution, and the Use of Historical Stereotypes to Legislate Sexuality.” John Marshall Law Review 2 1, no. 4 (1988): 777-830.

Bernat, Frances P. "New York State's Prostitution Statute:” Women Eீ Politics 4, no. 3 (October 1, 1984): 103-20.

Brandt, Allan M. "AIDS and Metaphor: Toward the Social Meaning of Epidemic Disease." Social Research 55, no. 3 (1988): 413-32.

Brock, Deborah R. Making Work, Making Trouble: The Social Regulation of Sexual Labour. Toronto: University of Toronto Press, 2009.

Brown, Merrill Washington Post Staff. “N.Y.'s Times Square to Get FaceLift: Developer, City Officials Announce \$1.6 Billion Office Complex \$1.6 Billion Project Set for New York's Times Square Area.” The Washington Post. December 21, 1983, sec. Business \& Finance.

Carmen, Arlene. Working Women: The Subterranean World of Street Prostitution. New York: Harper \& Row, 1985.

Carmody, Deirdre. "New York Is Facing 'Crisis' On Vagrants: Residents Fighting Efforts to Put Shelters in Their Communities Vagrants in New York Are Facing 'Crisis' in Neighborhood Hostility 36,000 Homeless in City A Danger in Large Facilities.” New York Times. June 28, 1981.

Certeau, Michel de. “General Introduction.” In The Practice of Everyday Life, xi xxiv. Berkeley, Calif.: University of California Press, 1984.

Chronopoulos, Themis. Spatial Regulation in New York City: From Urban Renewal to Zero Tolerance. New York: Routledge, 2011.

Cohen, Bernard. Deviant Street Networks: Prostitution in New York City. Lexington, Mass.: Lexington Books, 1980.

Cooney, Claire H, and Janet Quint. "Prostitution in New York City: Answers to Some Questions.” New York Women in Criminal Justice, June 1977. National Criminal Justice Reference Service. https://www.ncjrs.gov/pdffiles 1/Digitization/49950NCJRS.pdf. 
Corkin, Stanley. "Sex and the City in Decline: Midnight Cowboy (1969) and Klute (1971)." Journal of Urban History 36, no. 5 (2010): 617-33.

Daley, Suzanne. "Runaways Of 42d Street: Aids Begins Its Scourge.” New York Times, May 30, 1988, sec. Section 1.

Davidson, Roger., and Lesley A. Hall, eds. Sex, Sin, and Suffering: Venereal Disease and European Society Since 1870. New York: Routledge, 2001.

DeQuine, Jeanne. “AIDS Prostitute Freed Today.” USA Today, May 23, 1988, First edition, sec. News.

Douglas, Mary. Purity and Danger: An Analysis of Concepts of Pollution and Taboo. London: Routledge \& Kegan Paul, 1978.

Eckholm, Erik. "Prostitutes' Impact On Spread Of AIDS Is Debated: Officials Question Link Of AIDS and Prostitutes.” New York Times. November 5, 1985, sec. Science Times Education Style Arts.

Eckholm, Erik. "Prostitutes' Impact on Spread of Aids Is Developed.” New York Times, Late Edition (East Coast). November 5, 1985, sec. C.

Edelman, Bernard. "Shaking Down Atlantic City," Police Magazine, November 1982, 44-5.

French, Dolores. Working: My Life as a Prostitute. New York: E.P. Dutton, 1988. Friedman, Josh Alan. Tales of Times Square. New York: Delacorte Press, 1986.

Goodwin, Michael. "Koch Budget For'85 Allots Funds To Hire 1,000 More Officers.” New York Times, April 19, 1984, Late City Final Edition, sec. Metropolitan Desk; A.

Gross, Jane. “At New AIDS Test Center, Lives Are Changed.” New York Times, November 29, 1986, Final edition, sec. Metropolitan Desk, 1.

Hamill, Denis. "Going Bare-Fisted in the Park.” Newsday, City Edition. August 8, 1988, sec. NEWS.

—_. "Public Parks Without the Public." Newsday, City Edition. June 6, 1988, sec. NEWS.

—. "The End of Civilization as We Know It." Neresday, City Edition. August 29, 1988, sec. NEWS.

Hammett, William. "Vagrants Take Over Grand Central Subway.” New York Times. March 22, 1989, sec. Washington Talk.

Herman, Robin. "City Plans to Expand Use of Armories to House Homeless Men: 'A Municipal Flophouse' All Shelters Filled City Offers Plan to Put Homeless in Armories 'Should Not Be Surprised.” New York Times. December 1, 1981, sec. Metropolitan Report.

"If America Is Serious About AIDS; And Localities Must Fight for Drug Treatment: [Editorial].” New York Times, Late Edition (East Coast). June 5, 1988, sec. A.

Johnston, Jr., Robert J. "NYPD Report on Tompkins Square Park Incident.” NYPD, August 23, 1988.

https://dc.lib.jjay.cuny.edu/index.php/Detail/Object/Show/object_id/804.

Kolata, Gina. "Many With AIDS Said to Live In Shelters in New York City.” New Tork Times, April 4, 1988, Late City Final Edition, sec. Metropolitan Desk; B.

Leigh, Carol. Unrepentant Whore: The Collected Work of Scarlot Harlot. San Francisco, CA: Last Gasp, 2004. 
Leonard, Zoe, and Penny Thistlewaite. "Prostitution and HIV Infection.” In Women, AIDS, and Activism, edited by Marion. Banzhaf. Toronto: Between the Lines, 1990.

"LETTERS: New York's 'Best Housing Hop’ Is Dying".” New York Times, January 22, 1983, sec. Editorial Desk.

Levine, Philippa. Prostitution, Race, and Politics: Policing Venereal Disease in the British Empire. New York: Routledge, 2003.

Lewin, Tamar. "Rights of Citizens and Society Raise Legal Muddle on AIDS: Rights Issues Are Raising Legal Muddle on AIDS At What Point Should Society Isolate Disease Victims?” New York Times. October 14, 1987.

Meislin, Richard J. "Filtering the Dirt From the Energy Of Times Square: No One Is Sure Where the Less Attractive Elements of the Area Will Go Next." New Tork Times. August 31, 1987, sec. Metropolitan News.

Mele, Christopher. "Gentrification in Alphabet City." In From Urban Village to East Village: The Battle for New York's Lower East Side, edited by Janet L. AbuLughod. Cambridge, USA: Blackwell, 1994.

Mele, Christopher. Selling the Lower East Side: Culture, Real Estate, and Resistance in New York City. Minneapolis: University of Minnesota Press, 2000.

"People Who Live Somewhere Meet People Who Live Nowhere: [Letter][1]." New Tork Times, Late Edition (East Coast). September 29, 1986, sec. A.

Pheterson, Gail., ed. A Vindication of the Rights of Whores. Seattle, WA: Seal Press, 1989.

"Police and Protesters Have Clashed Before in Tompkins Square; Gentrification's Price: [Letter].” New York Times, Late Edition (East Coast). August 27, 1988 , sec. 1.

Powis, David. The Signs of Crime: A Field Manual for Police. London; New York: McGraw-Hill, 1977.

Purnick, Joyce. "City Cracks Down On Street Crimes.” New York Times, July 4, 1984, Late City Final Edition, sec. Metropolitan Desk; A.

Rangel, Jesus. "More Police To Combat 'Quality Of Life' Crimes.” New York Times, January 24, 1985, Late City Final Edition, sec. Metropolitan Desk; B.

—. "New York City Police Commissioner Benjamin Ward Says Police Department Is...” New York Times Abstracts, January 24, 1985, sec. Section 2.

Redfield RR, Markham PD, Salahuddin SZ, Wright DC, Sarngadharan MG, and Gallo RC. "Heterosexually Acquired HTLV-III/LAV Disease (AIDS-Related Complex and AIDS). Epidemiologic Evidence for Female-to-Male Transmission.” JAMA 254, no. 15 (1985): 2094-96.

Rimer, Sara. "FEAR OF AIDS GROWS AMONG HETEROSEXUALS.” New Tork Times, August 30, 1985, Late Edition, sec. A.

Ross, Becki L. "Sex and (Evacuation From) the City: The Moral and Legal Regulation of Sex Workers in Vancouver's West End, 1975-1985."

Sexualities 13, no. 2 (2010): 197-217.

Schanberg, Sydney H. "NEW YORK: 'I Live Here and You Don't'.” New York

Times, October 24, 1981, Late Edition, sec. Editorial Desk.

Schneider, Keith. "As Night Falls, Crime Moves Into Stuyvesant Square: Crime

Moves In to Stuyvesant Square.” New York Times. October 12, 1985, sec. Metropolitan Report Business Day Obituaries Style. 
Sciolino, Elaine. "Off the Street, Prostitution Is Flourishing." New York Times, Late Edition (East Coast). November 14, 1984, sec. B.

"Sex Business in Times Square Said to Decrease." New York Times, Late Edition (East Coast). May 31, 1984, sec. B.

Shenon, Philip. “Times Sq. Area Sweeps Have Tripled Arrests: Arrests Tripled by Police Sweeps Of Times Sq. Area on Weekends.” New Tork Times. August 22, 1983.

Shipp, E. R. "Residents of Many New York City Neighborhoods, Exasperated by What They See..." New York Times Abstracts, July 30, 1983, sec. Section 1.

Soffer, Jonathan M. Ed Koch and the Rebuilding of New York City. New York: Columbia University Press, 2010.

Sontag, Susan. Illness as Metaphor and AIDS and Its Metaphors. New York:

Picador/Farrar, 1990.

"The Economy of the Homeless; Children in a Sordid Sea: [EDITORIAL]." New Tork Times, Late Edition (East Coast). December 5, 1985, sec. A.

“The Feeble Fight Against AIDS: [Editorial]." New York Times, Late Edition (East Coast). July 14, 1986, sec. A.

The Homeless Won't Go Away.” New York Times. August 23, 1982.

"Why the Times Square We All Love and Hate Has Got to Go: [Letter]." New York Times, Late Edition (East Coast). July 4, 1986, sec. A.

Wines, Michael. "Class Struggle Erupts Along Avenue B: Class Struggle Erupts Along Ave. B The Police Missed the Protest's Roots, Which Was Not the Curfew, Some Say.” New York Times. August 10, 1988, sec. Metropolitan News.

Zausner, Michael. The Streets: A Factual Portrait of Six Prostitutes as Told in Their Own Words. New York: St. Martin’s Press, 1986. 